\title{
MODEL ONTOLOGI VARIETAS KELAPA SAWIT SEBAGAI DASAR SISTEM BERBASIS PENGETAHUAN RISET PERKEBUNAN
}

\section{ONTOLOGY MODEL OF OIL PALM VARIETIES FOR THE FOUNDATION OF PLANTATION RESEARCH KNOWLEDGE-BASED SYSTEM}

\author{
Arif Rakhman Hakim \\ PT Riset Perkebunan Nusantara \\ Jln. Salak No. 1A, Bogor, Indonesia, 15128 \\ Email: arif@rpn.co.id \\ Makalah: Diterima 27 September 2018; Diperbaiki 29 April 2019; Disetujui 15 Mei 2019
}

\begin{abstract}
Knowledge is an important asset that is easily lost. This loss process has a significant impact on plantation research organizations whose research takes a long time. This research aimed to develop an ontology model for recording knowledge about oil palm varieties. In order to save knowledge, in this research nine oil palm varieties were modeled into ontology using the Web Ontology Language $(O W L)$. Any information in oil palm varieties can be sorted and grouped into classes, object properties, data properties, or data expressions. The relationship between data in oil palm varieties can be well represented using ontology. Based on the results from HermiT reasoners, the ontologies with 43 classes are consistent. Information in the ontology of oil palm varieties can be easily rediscovered using the description logic query (DL-Query). The model produced from this research can be used as an initial model in designing knowledge management systems and ontology-based oil palm expert systems.
\end{abstract}

Keywords: ontology, OWL, oil palm seed, knowledge management

\section{ABSTRAK}

Pengetahuan adalah aset penting yang mudah hilang. Proses kehilangan ini berdampak signifikan pada organisasi riset perkebunan yang risetnya memerlukan waktu lama. Riset ini bertujuan menyusun model ontologi untuk merekam pengetahuan tentang varietas kelapa sawit. Untuk dapat menyimpan pengetahuan, dalam riset ini sembilan varietas kelapa sawit dimodelkan ke dalam bentuk ontologi menggunakan bahasa Web Ontology Language (OWL). Setiap informasi dalam varietas kelapa sawit dapat dipilah dan dikelompokkan ke dalam kelas, properti objek, properti data, atau ekspresi data. Hubungan antar data dalam varietas kelapa sawit dapat direpresentasikan dengan baik menggunakan ontologi.Hasil pengecekan menggunakan reasoner HermiT, ontologi dengan 43 kelas yang dibangun telah konsisten. Informasi di dalam ontologi varietas kelapa sawit ini dapat ditemukan kembali dengan mudah menggunakan metode description logic query (DL-Query). Model yang dihasilkan dari riset ini dapat digunakan sebagai model awal dalam perancangan sistem pengelolaan pengetahuan dan sistem pakar kelapa sawit berbasis ontologi.

Kata kunci: ontologi, OWL, varietas kelapa sawit, basis pengetahuan

\section{PENDAHULUAN}

Pengetahuan merupakan aset penting bagi organisasi riset. Aset penting ini bersifat mudah hilang. Hilangnya pengetahuan dapat berpengaruh signifikan pada organisasi, khususnya pada pengetahuan implisit pada kepakaran seseorang (tacit knowledge). Salah satu penyebab dominan hilangnya pengetahuan adalah pergantian personel di dalam organisasi (Daghfous et al., 2013). Pengetahuan di dalam organisasi akan terus muncul dan berubah antara bentuk ekplisit dan bentuk implisit melalui proses sosialisasi, eksternalisasi, internalisasi, dan kombinasi (Nonaka, 1994). Pengetahuan dapat perpindahan pengetahuan dari satu orang kepada orang lain di dalam organisasi, tetapi perpindahan tersebut tidak selalu berjalan lancar. Dalam proses perpindahan, pengetahuan mungkin berkurang atau terdistorsi sehingga tidak dapat diwariskan secara sempurna (Joeet al., 2013).

Organisasi riset di bidang perkebunan melaksanakan riset, seperti pemuliaan tanaman, yang memerlukan waktu lama untuk mendapatkan hasil. Satu riset varietas kelapa sawit tahan penyakit busuk pangkal batang (basal stem rot) memerlukan tahapan penelitian yang panjang, meliputi seleksi induk, pengujian terhadap ketahanan penyakit di lokasi yang endemik dengan skala luas, serta penilaian kinerja produksi tandan buah segar (TBS). Waktu yang dibutuhkan untuk meneliti varietas kelapa sawit sampai tanaman mencapai masa tidak produktif sekitar 25 tahun (Wong dan Bernard, 2008). Dengan karakteristik riset yang memerlukan waktu lama dan melibatkan peneliti multidisiplin, organisasi riset bidang perkebunan sangat rentan terhadap kehilangan pengetahuan. 
Untuk mempertahankan pengetahuan yang telah dihasilkan dari proses riset, organisasi riset memerlukan metode untuk menyimpan pengetahuan. Pengetahuan dapat disimpan setelah dieksplisitkan sehingga mudah ditangani dan diolah. Salah satu pendekatan untuk mengeksplisitkan pengetahuan adalah menggunakan model ontologi. Model ontology merupakan spesifikasi eksplisit dari sebuah konseptualisasi yang merepresentasikan objek yang menarik perhatian (object of interest) serta merepresentasikan hubungan antar objek (Gruber, 1993). Contoh ontologi dalam bentuk yang sederhana telah disampaikan oleh Guarino et al. (2009) (Gambar 1). Ontologi dapat ditulis dalam format Web Ontology Language (OWL) yang dapat diintegrasikan dengan teknologi internet sehingga memudahkan proses sharing pengetahuan. Di samping itu, basis komputasi OWL adalah berbasis logika (computational logic-based) sehingga memungkinkan penarikan kesimpulan (reasoning) dan verifikasi konsistensi pengetahuan oleh program komputer (reasoner)(Hitzler et al., 2012).

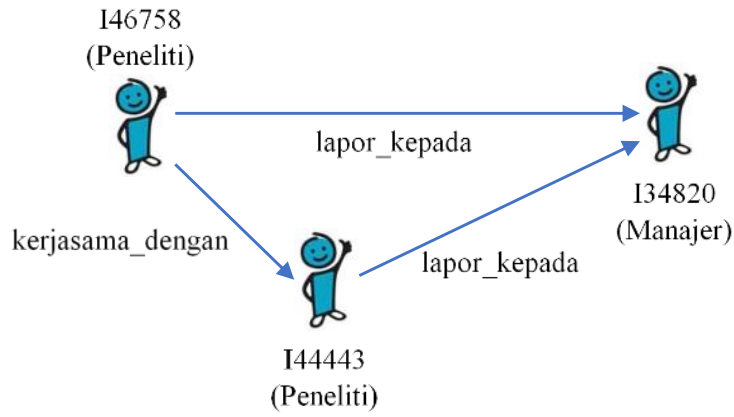

Gambar 1. Ontologi sistem manajemen SDM suatu perusahaan (Guarino et al., 2009)

Model ontologi telah digunakan dalam sistem asisten pengemudi pintar (Intelligent Driver Assistance System) untuk merepresentasikan data mengenai objek-objek dan hubungan masing-masing pada aktivitas asistensi mengemudi (Kannan et al., 2010). Di bidang biologi molekuler, ontology digunakan untuk merekam pengetahuan tentang biologi molekuler oleh Gene Ontology Consortium (GOC). Gene Ontology (GO ) memiliki tiga fungsi utama dalam representasi: 1)proses biologis (proses di mana gen atau produk gen terlibat), 2) fungsi molekuler (aktivitas biokimia produk gen), dan 3) komponen sel (lokasi di mana produk gen aktif) (Gene Ontology Consortium, 2000). Data pada GO telah mencapai lebih dari 53 juta data (lebih dari 460.000) spesies makhluk hidup. Saat ini GO mulai dikembangkan juga untuk merepresentasikan proses mikrobiologi (Gene Ontology Consortium, 2013; Gene Ontology Consortium, 2015). Dengan adanya GO, maka proses analisis dan eksplorasi menjadi lebih mudah, serta dapat memberikan pandangan baru dalam mempelajari fungsi-fungsi mikrobiologi (Deng et al., 2015). Pengetahuan yang telah dimodelkan ke dalam bentuk ontologi sangat mendukung interoperability dan input bagi decision support system (De Potter et al., 2012).

Di bidang yang terkait dengan pertanian, ontologi mulai banyak digunakan di antaranya adalah riset yang dilaksanakan oleh (Silalahi, 2016; Silalahi et al., 2015). Dalam riset tersebut, ontologi digunakan untuk menyimpan pengetahuan dari lima sumber, yaitu: 1) farmakologi, 2) praktisi kesehatan, 3) taksonomi tanaman, 4) budidaya tanaman, dan 5) konservasi tanaman obat langka. Abu Bakar dan Ismail (2013) mengembangkan ontologi dasar untuk durian dengan nama DuriO. Dalam pengembangan DuriO, Abu Bakar dan Ismail (2013) melakukan validasi menggunakan SPARQL untuk melakukan query dan mengecek hasil query. Apabila hasil query sesuai dengan kondisi riil, maka ontologi dinyatakan valid. Selain DuriO, ontologi lain yang dikembangkan untuk pertanian adalah AgOnt yang bersifat lebih umum daripada DuriO. AgOnt fokus pada terminologi dan daur hidup komoditas pertanian. AgOnt utamanya ditujukan untuk mengintegrasikan komoditas yang terdistribusi dalam satu bahasa yang disepakati bersama ( $\mathrm{Hu}$ et al., 2011).

Riset ini bertujuan menyusun model ontologi untuk merekam pengetahuan tentang varietas kelapa sawit. Model ini dapatmenjadi pondasi dalam membangun sistem penyimpanan pengetahuan kelapa sawit yang dihasilkan oleh organisasi riset perkebunan untuk mencegah hilangnya pengetahuan yang berharga.

\section{METODE PENELITIAN}

Data yang digunakan dalam risetini terdiri dari dua jenis:

1. Data karakteristik sembilan varietas unggul kelapa sawit yang dimiliki oleh Pusat Penelitian Kelapa Sawit (PPKS), yaitu 1) DyxP Sungai Pancur 1, 2) DxP AVROS, 3) DxP Simalungun, 4) DxP PPKS 540, 5) DxP 540 NG, 6) DxP Yangambi, 7) DxP PPKS 718, 8) DxP PPKS 239, dan 9) DxP Langkat (kode DxP atau DyxP merupakan kode induk persilangan selanjutnya tidak akan dicantumkan). Data ini berbentuk tabel seperti contoh pada Tabel 1.

2. Fakta-fakta terkait kelapa sawit yang sifatnya umum, seperti:

- Sungai Pancur 1 adalah varietas kelapa sawit,

- varietas kelapa sawit adalah kelapa sawit,

- kelapa sawit adalah tanaman,

- kelapa sawit menghasilkan tandan buah segar, dan

- Ganoderma boninense adalah penyebab busuk pangkal batang (basal stem rot).

Tahapan penyusunan ontologi mengikuti metode yang dirancang oleh Fernández-Lópezet al. (1997) yang disebut dengan Methontology. Setelah 
pengetahuan dan data diperoleh, proses representasi ontologi dimulai dengan identifikasi tripel (triples) yang umumnya berbentuk subjek-predikat-objek (Spyns dan Reinberger, 2005). Data karakteristik dan fakta kelapa sawit yang telah dikumpulkan disusun menjadi bentuk subjek-predikat-objek atau subjek-predikat-objek-keterangan. Untuk memudahkan penyusunan tripel, maka predikat yang digunakan yaitu "adalah" atau "memiliki". Contoh dari rerata jumlah tandan (lihat Tabel 1) dan fakta "kelapa sawit menghasilkan tandan buah segar" dibentuk menjadi format seperti pada Gambar 2.

Setiap suku kata dalam tripel diklasifikasikan ke dalam kelas (class), properti objek (object property), properti data (data property), atau ekspresi data (data expression) dengan aturan sebagai berikut:

- semua subjek menjadi kelas,

- semua objek yang tidak diikuti keterangan menjadi kelas,

- semua predikat yang diikuti objek tanpa keterangan menjadi properti objek,

- semua predikat-objek yang diikuti keterangan bukan angka menjadi properti objek, contoh: "memiliki hasil" menjadi propertiobjek "hasProduct",

- semua predikat-objek atau predikat-objekketerangan yang diikuti keterangan nilai menjadi properti data, contoh: "memiliki rerata jumlah tandan" menjadi property data "has Avarage Bunch", "memiliki potensi produksi CPO" menjadi "has Cpo-Production Potency",

- semua keterangan angka menjadi ekspresi data, dan

- semua keterangan satuan menjadi kelas.

Tripel-tripel tersebut kemudian ditulis dalam format OWL dengan bantuan Protégé System 5.2.0 (Musen, 2015). Aturan penulisan kelas, properti objek, properti data, dan aksioma dalam penyusunan ontologi mengacu pada laporan teknis yang dikeluarkan oleh W3C (Hitzler et al., 2012). Proses verifikasi ontologi dilakukan metode reasoning HermiT (Sheareret al., 2008; Glimm et al., 2014) untuk mengetahui konsistensi yang ontologi yang dibangun.

Tabel 1. Data karakteristik Varietas Kelapa Sawit Sungai Pancur 1

\begin{tabular}{|c|c|c|}
\hline Karakteristik & Nilai & Keterangan/Satuan \\
\hline Rerata jumlah tandan & 8 & tandan/pohon/th \\
\hline Rerata berat tandan & 25 & $\mathrm{~kg} /$ tandan \\
\hline Potensi produksi TBS & 32 & ton/ha/th \\
\hline Rendemen & 26 & $\%$ \\
\hline Potensi CPO & 7,5 & ton/ha/tahun \\
\hline Potensi PKO & 0,9 & ton/ha/tahun \\
\hline Potensi CPO + PKO & 8,4 & ton/ha/tahun \\
\hline Iodine Value & 54,1 & - \\
\hline Kandungan beta karoten & 354 & ppm \\
\hline Pertumbuhan meninggi & $40-55$ & $\mathrm{~cm} /$ tahun \\
\hline Panjang pelepah & 6,2 & M \\
\hline Kerapatan tanam & 130 & pohon/ha \\
\hline Umur panen & $28-30$ & bulan \\
\hline Adaptasi pada daerah marjinal & Baik & Beradaptasi baik pada lahan gambut dan pasang surut \\
\hline
\end{tabular}

Sumber(Fadli et al., 2017)

\begin{tabular}{|c|c|c|c|c|}
\hline Dy x P Sungai Pancur 1 & memiliki & rerata jumlah tandan & \multicolumn{1}{|c|}{ tandan/pohon/th } \\
\hline S & $\mathrm{O}$ & Ket. Angka & Ket. Satuan
\end{tabular}

\begin{tabular}{|ccc|c|c|}
\hline Kelapa sawit & memiliki & hasil & tandan buah segar \\
& $\mathrm{P}$ & $\mathrm{O}$ & $\mathrm{K}$
\end{tabular}

Gambar 2. Contoh hasil konversi data menjadi tripel 


\section{HASIL DAN PEMBAHASAN}

Data varietas kelapa sawit yang digunakan dapat dirinci menjadi sembilan belas karakter besar. Data tersebut dapat diklasifikasikan menjadi tiga bentuk data, yaitu teks (string), bilangan bulat (integer), dan bilangan desimal (float) (Tabel 3. ). Dengan mengambil contoh pada Tabel 1, terdapat karakter yang dapat dipecah menjadi dua, yaitu karakter "Adaptasi Daerah Marjinal". Adaptasi terhadap daerah marjinal memuat karakter "Adaptasi Lahan gambut" dan "Adaptasi Lahan Pasang Surut". Oleh sebab itu, data field"Adaptasi Lahan Marjinal" memiliki dua sub kelas, yaitu "Adaptasi Lahan Gambut" dan "Adaptasi Lahan Pasang Surut".

Dari data tersebut, terdapat karakter berupa nilai fuzzy dalam bentuk penilaian kualitatif berdasarkan skala Likert (Matell dan Jacoby, 1971). Karakter tersebut adalah 1) "Adaptasi Lahan Marjinal", 2) "Adaptasi Lahan Gambut", 3) "Adaptasi Lahan Pasang Surut", dan 4) "Ketahanan Busuk Pangkal Batang”. Keempat karakter tersebut direpresentasikan dalam tipe data stringd engan nilai direpresentasikan dengan kata "sangat baik" (very good), "baik" (good), "wajar" (normal), "buruk" $(b a d)$, dan "sangat buruk" (very bad). Dengan memperhatikan aturan di atas, nilai fuzzy ini direpresentasikan menjadi kelas dan dikelompokkan ke dalam kelas tersendiri dan diberi label
"ValuePartition. Kelas "ValuePartition" berfungsi untuk menampung semua pengukuran dan penilaian terhadap varietas kelapa sawit.

Tabel 2. Bidang data varietas kelapa sawit

\begin{tabular}{lc}
\hline Data Field & Bentuk Data \\
\hline Nama Varietas & Teks \\
Grup Varietas & Bil. Bulat \\
Rerata Jumlah Tandan & Bil. Bulat \\
Rerata Berat Tandan & Desimal \\
Potensi Produksi TBS & Desimal \\
Potensi CPO & Desimal \\
Potensi PKO & Desimal \\
Potensi CPO + PKO & Desimal \\
Rendemen & Desimal \\
Iodine Value & Desimal \\
Kandungan Beta Karoten & Bil. Bulat \\
Pertumbuhan Meninggi & Desimal \\
Panjang Pelepah & Desimal \\
Kerapatan Tanam & Bil. Bulat \\
Umur Panen & Bil. Bulat \\
Adaptasi Daerah Marjinal & Teks \\
Adaptasi Lahan Gambut & Teks \\
Adaptasi Pasang Surut & Teks \\
Ketahanan Basuk Pangkal & Teks \\
Batang & \\
\hline
\end{tabular}

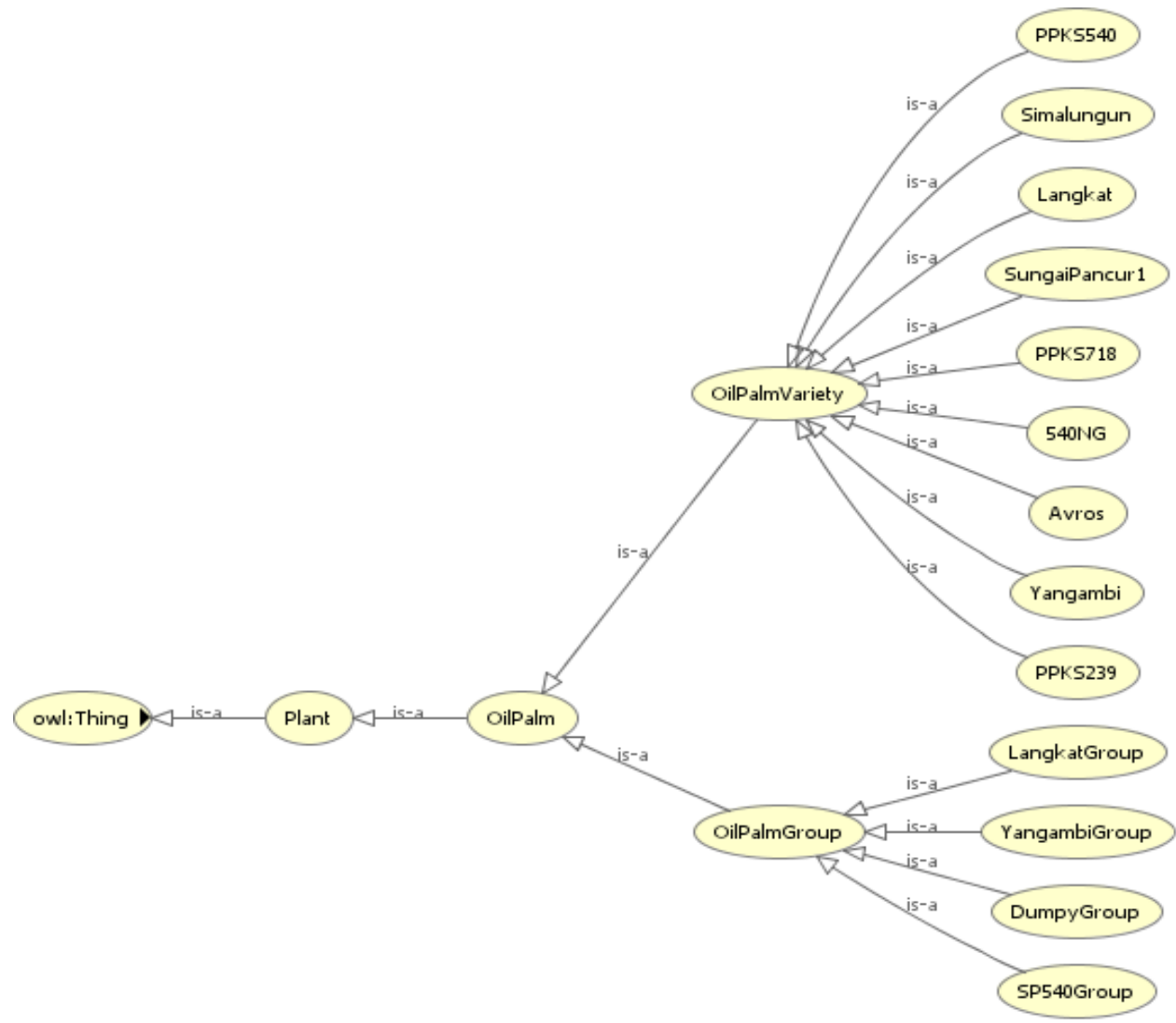

Gambar 3. Potongan ontologi varietas kelapa sawit pada kelas OilPalm 
Kelas pada ontologi varietas kelapa sawit yang dirancang pada penelitian ini terdiri lima tingkatan. Dengan tingkatan pertama adalah kelas "Thing" (owl:Thing) yang menjadi akar kelas (root class) dari semua kelas pada Protégé System (Noyet al., 2000). Kelas ini memiliki lima sub kelas sebagaimana ditampilkan pada Tabel 3. Secara visual, kelas Oil Palm beserta sub kelasnya ditampilkan pada Gambar 3.Kelas-kelas pada ontologi ini dihubungkan oleh properti objek sesuai dengan fakta kelapa sawit yang telah dikumpulkan. Sebagai contoh, antara anggota kelas "OilPalmVariety" dengan "OilPalmGroup" dihubungkan dengan properti objek "hasGroup", properti ini merepresentasikan bahwa varietas kelapa sawit yang ada memiliki grup tertentu. Sebagai contoh adalah varietas kelapa sawit 540 NG, Avros, PPKS 540, dan Simalungun yang termasuk ke dalam grup SP 540 (Gambar 4).

Setiap varietas kelapa sawit memiliki properti sesuai dengan data karakteristik varietas masing-masing. Sebagai contoh, varietas Sungai Pancur 1 (Tabel 1) dapat direpresentasikan dalam bentuk ontologi seperti pada Gambar 5. Setiap karakteristik varietas yang berupaangka ditulis berdasarkan bentuk datanya, apakah berupa bilangan bulat atau bilangan desimal.

Tabel 3. Kelas pada ontologi varietas kelapa sawit

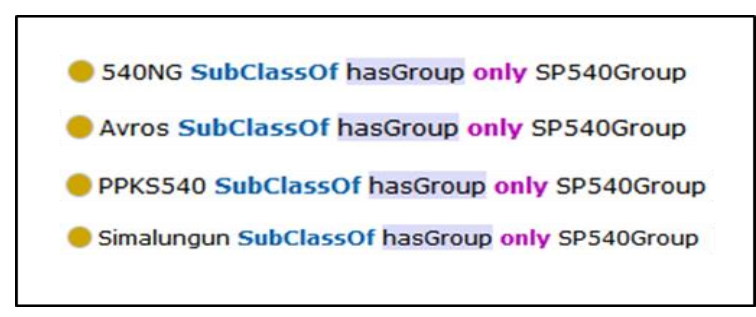

Gambar 4. Representasi hubungan "hasGroup" pada empat varietas kelapa sawit pada grup SP 540

Dalam format OWL, kedua bentuk data tersebut ditulis dengan cara yang berbeda. Bilangan bulat ditulis secara langsung berupa angka atau dengan keterangan"xsd:integer", sedangkan bilangan desimal ditulis dengan akhiran huruf " $\mathrm{f}$ " atau dengan keterangan "xsd:float". Untuk nilai yang lebih kompleks seperti nilai berupa rentang harus ditulis dengan notasi khusus. Sebagai contoh, karakter pertumbuhan meninggi dengan nilai 40-55 dituliskan dengan "hasGrowthRatesome (xsd:float[>=40.0f] and xsd:float $[<=55.0 \mathrm{f}]$ ). Metode ini adalah penerapan dari dasar operasi himpunan interseksi (intersection).

\begin{tabular}{ll}
\hline \multicolumn{1}{c}{ Kelas } & \\
\hline Plant & Semua pengetahuan tentang tanaman atau tumbuhan \\
- OilPalm & Semua pengetahuan tentang kelapa sawit \\
- - OilPalmGroup & Pengetahuan tentang grup-grup dalam kelapa sawit, yaitu Dumpy, \\
& Langkat, SP 540, dan Yangambi (masing-masing menjadi kelas \\
& tersendiri) \\
- - OilPalmVariety & Pengetahuan tentang varietas yang terdapat dalam kelapa sawit, yaitu \\
& 540 NG, Avros, Langkat, PPKS 239, PPKS 540, PPKS 718, \\
& Simalungun, Sungai Pancur 1, dan Yangambi (masing-masing \\
& menjadi kelas tersendiri) \\
Commodity & Pengetahuan tentang komoditas yang dihasilkan pada budidaya kelapa \\
& sawit \\
- FreshFruitBunch & Pengetahuan tentang tandan buah segar (TBS) \\
- PalmOil & Pengetahuan tentang hasil olahan TBS berupa Crude Palm Oil (CPO) \\
& dan Palm Kernel Oil (PKO) (masing-masing menjadi kelas sendiri) \\
OilPalmDesease & Konsep penyakit yang dapat menyerang kelapa sawit \\
- BasalStemRot & Konsep penyakit busuk pangkal batang \\
OilPalmPathogen & Konsep makhluk hidup yang dapat mengakibatkan penyakit pada \\
& kelapa sawit \\
- GanodermaBoninense & Jamur penyebab busuk pangkal batang, yaitu Ganoderma boninense \\
ValuePartition & Konsep yang berupa nilai atau ukuran yang digunakan dalam konteks \\
& kelapa sawit \\
- FuzzyValue & Nilai fuzzy yang digunakan dalam pengukuran kelapa sawit \\
- UnitOfMeasurement & Satuan-satuan yang digunakan dalam karakteristik kelapa sawit \\
\hline
\end{tabular}

Keterangan: Tanda(-)merepresentasikan sub kelas; tanda (- -) merepresentasikan sub dari sub kelas 


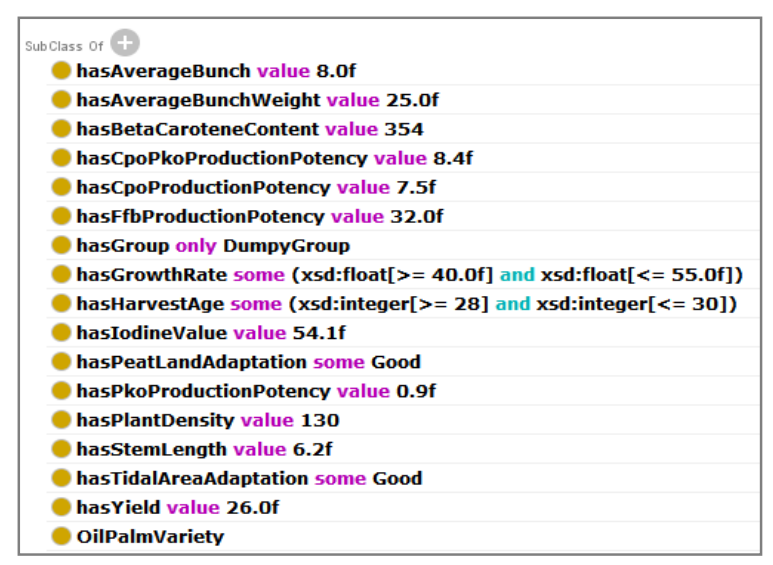

Gambar 5. Pemodelan sifat Sungai Pancur 1 dalam format Protégé

Ontologi teknologi varietas kelapa sawit yang dihasilkan diverifikasi dengan reasoned HermiT (Sheareret al., 2008; Glimm et al., 2014). Reasoner HermiT dapat bekerja dengan baik untuk pengecekan konsistensi ontologi skala kecil sebagaimana pada ontologi dalam riset ini (43 kelas, 26 properti, dan 296 aksioma). Berdasarkan hasil pengujian yang dilakukan oleh (Glimm et al., 2014) pada beberapa contoh ontologi dengan jumlah kelas mulai dari 43 hingga 150.000 , reasoner HermiT optimal dalam melakukan pengecekan konsistensi khususnya pada ontologi dengan kompleksitas tinggi. Metode ini melakukan pengecekan konsistensi hubungan dan properti pada tiap kelas di dalam ontologi. Reasoner HermiT akan memberikan tanda warna merah pada kelas yang tidak konsisten, baik akibat pola hubungan maupun properti yang tidak konsisten (Gambar 6). Warna merahakan hilang apabila kelas telah diperbaiki atau dipindahkan ke dalam sub kelas yang sesuai dengan rekomendasi reasoner HermiT.

Model ontologi yang dirancang dapat berevolusi sesuai dengan pengetahuan-pengetahuan baru yang diperoleh. Sebagai contoh, saat ini dalam "OilPalmDesease" hanya terdiri dari satu jenis penyakit, yaitu busuk pangkal batang (basal stem rot) sesuai dengan data yang tersedia. Kelas ini dapat ditambahkan dengan jenis-jenis penyakit lain yang dapat menyerang kelapa sawit. Demikian juga dengan kelas "Plant", kelas ini dapat menampung pengetahuan tentang tanaman lain sesuai dengan kebutuhan dalam pengelolaan pengetahuan. Kelas "Plant" dapat menyimpan datatentang tanaman kopi, kakao, karet, teh, tebu, dan tanaman komersial lainnya apabila kelas "Plant" hendak diperluas untuk tanaman komersial lainnya. Arah evolusi tersebut sejalan dengan pengetahuan-pengetahuan baru yang ditangkap dan disesuaikan dengan kebutuhan terhadap fungsi ontologi itu sendiri (Zablith et al., 2015).

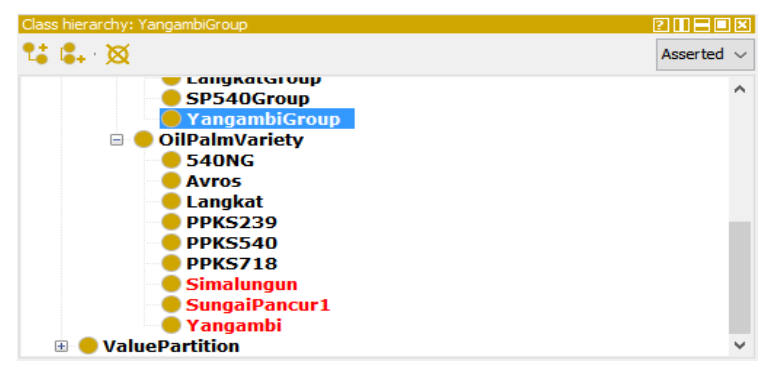

Gambar 6. Contoh hasil pengecekan ontologi dengan reasoner HermiT

Data varietas kelapa sawit yang disimpan dalam bentuk ontologi dapat diperoleh kembali menggunakan DL-Query (Motiket al., 2005). DLQuery menggunakan notasi yang mendekati bahasa natural sehingga memudahkan pencarian informasi. Informasi tentang varietas kelapa sawit dengan jumlah tandan rata-rata lebih dari 14,0 dapat dicari dengan pertanyaan (query):

"OilPalmVariety that hasAverageBunch some xsd:float $[>=14]$ ".

Pertanyaan ini akan memunculkan tiga varietas kelapa sawit, yaitu:

- 540NG (jumlah tandan rata-rata 14,0),

- PPKS 239 (jumlah tanda rata-rata 15,0), dan

- PPKS 540 (jumlah tanda rata-rata 14,0).

Penggantian notasi "OilPalmVariety" pada pertanyaan dengan "OilPalm", "Plant", atau bahkan menghilangkan notasi tersebuttidak akan berpengaruh terhadap hasil yang diperoleh. Hal ini dikarenakan kelas "OilPalmVariety" termasuk ke dalam "OilPalm" dan "Plant" sehingga memberikan hasil sama. Adapun pertanyaan tanpa menyebutkan secara spesifik kelas akan memberikan hasil semua kelas dengan properti data "hasAverageBunch" dengan nilai lebih dari 14,0.

Dari hasil riset, ontologi memiliki fungsi yang cukup dan sangat fleksibel untuk merepresentasikan pengetahuan. Meskipun demikian, ontologi masih memiliki berapa kelemahan seperti masih dianggap sulit untuk dirancang dan memerlukan upaya yang besar untuk implementasinya. Ontologi juga dianggap masih terlalu rigid untuk merepresentasikan dunia riil yang bersifat dinamis dan kompleks (Brewster dan O’Hara, 2007), meskipun pada skala operasional kelemahan ini tidak berdampak signifikan sebagaimana yang telah dibuktikan oleh peneliti sebelumnya bahwa ontologi dapat digunakan pada domain masing-masing. Di samping itu, ketersediaan mesin reasoning yang dapat di-scale-up masih terbatas (Hastings, 2017). Meskipun demikian, solusi-solusi terhadap keterbatasan ontologi diharapkan akan bermunculan dengan semakin banyaknya kontributor yang meneliti ontologi (Brewster dan O’Hara, 2007). 
Tidak semua pengetahuan dapat direpresentasikan secara sempurna oleh ontologi tanpa ada modifikasi. Misalnya nilai fuzzy yang telah dibahas sebelumnya (Brewster dan O'Hara, 2007). Meskipun secara sederhana nilai fuzzy dapat dinyatakan dalam kelas tersendiri, tetapi secara matematis tidak memberikan implikasi khusus. Pendekatan yang dapat digunakan untuk mendukung nilai fuzzy secara matematis adalah menggunakan metode yang dikembangkan oleh Huitzil et al. (2018). Selain nilai fuzzy, ontologi tanpa modifikasi juga belum mampu merepresentasikan pengetahuan statistik, kondisional, dan pengetahuan yang sifatnya dinamis terhadap waktu secara langsung.

Secara umum, model ontologi dapat digunakan untuk menyimpan datavarietas kelapa sawit. Sebagaimana yang sudah dijelaskan di atas, ontologi dapat menampung informasi sifat kelapa sawit baik yang berbentuk teks, maupun yang berbentuk bilangan. Di samping itu, ontologi dapat menyimpan hubungan antar objek dalam bidang perkelapasawitan seperti varietas, grup, penyakit, organisme patogen, hingga pada satuan ukuran yang digunakan. Ontologi ini dapat berkembang dengan masuknya pengetahuan-pengetahuan baru sebagaimana yang telah dilakukan pada GO (Gene Ontology Consortium, 2013; Gene Ontology Consortium, 2015). Hasil penelitian ini memberikan implikasi bahwa ontologi dapat digunakan sebagai basis pengembangan sistem pengelolaan pengetahuan dan sistem pakar tentang kelapa sawit. Hal ini didukung kuat dengan kemudahan proses temu kembali informasi dalam model ontologi.

\section{KESIMPULAN DAN SARAN}

\section{Kesimpulan}

Ontologi dapat digunakan untuk menyimpan pengetahuan tentang kelapa sawit seperti nama varietas, grup, dan karakter pada masing-masing varietas kelapa sawit. Berbagai bentuk informasi terkait dengan varietas kelapa sawit, baik dalam bentuk teks, bilangan bulat, dan bilangan desimal dapat tersimpan dalam format OWL. Representasi pengetahuan dalam format OWL merupakan pilihan yang tepat untuk menyimpan pengetahuan dengan mempertimbangkan kemudahannya dalam proses temu kembali, kemampuannya untuk digunakan sebagai media sharing (interoperability), kemudahan dalam melakukan pengecekan konsistensi pengetahuan yang tersimpan, serta fleksibilitas dalam penyimpanan data baru. Setiap objek dan data dapat disimpan, baik dalam bentuk kelas, properti objek, properti data, maupun ekspresi data.

\section{Saran}

Model yang dihasilkan dari riset ini dapat digunakan sebagai model awal dalam perancangan sistem pengelolaan pengetahuan dan sistem pakar kelapa sawit berbasis ontologi.

\section{UCAPAN TERIMA KASIH}

Ucapan terima kasih penulis sampaikan kepada Tim dari Biro Komersial dan Bisnis PT Riset Perkebunan Nusantara yang telah memberikan akses data dan informasi varietas kelapa sawit.

\section{DAFTAR PUSTAKA}

Abu BZ dan Ismail KN. 2013. Base Durian Ontology Development Using Modified Methodology. Di dalam Noah S.A. et al (ed.). Soft Computing Applications and Intelligent Systems. M-CAIT 2013. Communications in Computer and Information Science, Vol 378. Berlin, Heidelberg: Springer. P206-218, doi:10.1007/978-3-642-40567-9_18.

Brewster C dan O'Hara K. 2007. Knowledge representation with ontologies: present challenges - future possibilities. International Journal of Human-Computer Studies 65 (7): 563-68, doi:10.1016/j.ijhcs.2007.04.003.

Daghfous A, Belkhodja O, dan Angell LC. 2013. Understanding and managing knowledge loss. Journal of Knowledge Management 17 (5): 639-60, doi:10.1108/JKM-12-2012-0394.

De Potter P, Cools H, Depraetere K, Mels G, Debevere P, De Roo J, Huszka C, Colaert D, Mannens E, de Walle RV. 2012. Semantic Patient Information Aggregation and Medicinal Decision Support. Computer Methods and Programs in Biomedicine 108 (2): 724-735, doi:10.1016/j.cmpb. 2012.04.002.

Deng SP, Chen ZD, Chen L, Ding GH, Li YX. 2015. An Integrated Strategy for Functional Analysis in 16S rRNA Gene-Based Research of Microbial Communities by GENE ONTOLOGY.International Journal of Data Mining and Bioinformatics 13 (1): 63-74, doi:10.1016/J.Egypro.2011.10.684.

Fadli L, Hakim AR, Setiadi D, Mawardhi AD. 2017. Katalog Bahan Tanam Perkebunan. Edisi Pertama. Bogor: PT Riset Perkebunan Nusantara.

Fernández-López M, Gómez-Pérez A, Juristo N. 1997. METHONTOLOGY: From Ontological Art Towards Ontological Engineering. Proceedings of the Ontological Engineering AAAI-97 Spring Symposium Series, 33-40. Stanford University, California, Amerika Serikat.

Gene Ontology Consortium. 2000. Gene ontology: tool for the unification of biology. Nature Genetics 25: 25-29.

Gene OntologyConsortium. 2013. Gene ontology annotations and resources. Nucleic Acids 
Research 41: 530-535, doi:10.1093/nar/g ks1050.

Gene Ontology Consortium. 2015. Gene ontology consortium: going forward. Nucleic Acids Research 43: D1049-56. doi:10.1093/nar/ gku1179.

Glimm B, Horrocks I, Motik B, Stoilos G, Wang Z. 2014. HermiT: An OWL 2 Reasoner. Journal of Automated Reasoning 53 (3): 245-69, doi:10.1007/s10817-014-9305-1.

Gruber TR. 1993. A translation approach to portable ontology specifications. Knowledge Acquisition. 5 (2): 199-220.

Guarino N, Oberle D, dan Staab S. 2009. What Is an Ontology?.Di dalam Studer R dan Staab S (ed.). Handbook on Ontologies. New York: Springer, New York. P1-17.

Hastings J. 2017. Primer on ontologies. di dalam dessimoz c, škunca $\mathrm{N}$ (ed.). The Gene Ontology Handbook. Methods in Molecular Biology, vol 1446. New York: Humana Press. P3-13. doi:10.1007/978-1-4939-3743-1_1.

Hitzler P, Krötzsch M, Parsia B, Patel-Schneider PF, Rudolph S. 2012. OWL 2 Web Ontology Language Primer (Second Edition). W3C. https://www.w3.org/TR/2012/REC-owl2primer-20121211/. Diakses pada 26 Juli 2017.

Hu S, Wang H, She C, Wang J. 2011. AgOnt: Ontology for Agriculture Internet of Things. Di dalam Li D, Liu Y, Chen Y(ed.).4th Conference on Computer and Computing Technologies in Agriculture (CCTA). Berlin, Heidelberg: $\quad$ Springer. P131-137, doi:10.1007/978-3-642-18333-1_18.

Huitzil I, Straccia U, Díaz-Rodríguez N, Bobillo F. 2018. Datil: Learning Fuzzy Ontology Datatypes. Di dalam Medina J. et al (ed.).Information Processing and Management of Uncertainty in KnowledgeBased Systems. Theory and Foundations. IPMU 2018. Communications in Computer and Information Science, Vol 854. Cham: Springer. P100-112, doi:10.1007/978-3-31991476-3_9.

Joe C, Yoong P, Patel K. 2013. Knowledge loss when older experts leave knowledge-intensive organisations. Journal of Knowledge Management 17 (6): 913-27, doi:10.1108/ JKM-04-2013-0137.

Kannan S, Thangavelu A, dan Kalivaradhan R. 2010. An intelligent driver assistance system (i-das) for vehicle safety modelling using ontology approach. International Journal of UbiComp 1 (3): 15-29, doi:10.5121/ iju.2010.1302.
Matell MS dan Jacoby J. 1971. Is there an optimal number of alternatives for likert scale items? study i: reliability and validity. Educational and Psychological Measurement 31: 657-74, doi:10.1177/001316447103100307.

Motik B, Sattler U, dan Studer R. 2005. Query answering for OWL-DL with rules.Web Semantics: Science, Services and Agents on the World Wide Web 3 (1): 41-60, doi:10.1016/j.websem.2005.05.001.

Musen MA. 2015. The protégé project: a look back and a look forward. AI Matters 1 (4): 4-12.

Nonaka I. 1994. A Dynamic theory of organizational knowledge creation. Organization Science 5 (1): 14-37.

Noy N, Fergerson R, dan Musen M. 2000. The Knowledge Model of Protege-2000: Combining Interoperability and Flexibility. Di dalam Dieng R dan Corby O (ed.).Knowledge Engineering and Knowledge Management Methods, Models, and Tools. Perancis: Springer.P69-82.

Shearer R, Motik B, dan Horrocks I. 2008. HermiT : A Highly-Efficient OWL Reasoner.Proceedings of the 5th International Workshop on OWL: Experiences and Directions (OWLED), 432:91.

Silalahi M, Cahyani DE, Sensuse DI, Budi I. 2015. Developing Indonesian medicinal plant ontology using socio-technical approach. I4CT 2015 - 2015 2nd International Conference on Computer, Communications, and Control Technology, Art Proceeding: 3943, doi:10.1109/I4CT.2015.7219533.

Silalahi M. 2016. A meta design approach in ontology construction support for social and technical sub-system. International Journal of Computer Science and Application 5 (2): 3543, doi:10.12783/ijcsa.2016.0502.02.

Spyns P dan Reinberger M. 2005. Lexically evaluating ontology triples generated automatically from texts. in: a. gómez-pérez and j. euzenat. Proceedings of the 2nd European Semantic Web Conference 3532:563-577.

Wong CK dan Bernard R. 2008. Genomewide selection in oil palm: increasing selection gain per unit time and cost with small populations. Theoretical and Applied Genetics. 116 (6): 815-24.

Zablith F, Antoniou G, d'Aquin M, Flouris G, Kondylakis H, Motta E, Plexousakis D, Sabou M. 2015. Ontology evolution: a processcentric survey. The Knowledge Engineering Review 30 (1): 45-75, doi:10.1017/ S0269888913000349. 